УДК 625

\title{
ЗАЛІЗНИЧНА КОЛІЯ В СУЧАСНИХ УМОВАХ ТА ЇЇ ПОСИЛЕННЯ
}

\author{
О.І. Прокопенко, канд. техн. наук В.Г. Мануйленко
}

\section{ЖЕЛЕЗНОДОРОЖНЫЙ ПУТЬ В СОВРЕМЕННЫХ УСЛОВИЯХ И ЕГО УСИЛЕНИЕ}

\author{
А.И. Прокопенко, канд. техн. наук В.Г. Мануйленко
}

\section{RAILROAD IN THE PRESENT CONDITIONS AND ITS AMPLIFICATION}

\section{O.I. Prokopenko, cand. of techn. sciences V.G. Manuylenko}

Стратегія розвитку залізничного транспорту Украӥни передбачає зростання обсягу перевезень вантажів, будівництво нових і реконструкиію існуючих залізничних ліній, введення швидкісного і високошвидкісного руху. Для досягнення ичх показників необхідно розробити більш досконалі елементи руху, включаючи підщпальну основу - земляне полотно і баластний шар.

Ключові слова: земляне полотно, трунти, покриття, розрахунок, посилення.

Стратегия развития железнодорожного транспорта Украины предусматривает рост объема перевозок грузов, строительство новых и реконструкиию существующих железнодорожных линий, введение скоростного и высокоскоростного движения. Для достижения этих показателей необходимо разработать более совершенные элементы движения, включая подшпальную основу земляное полотно и балластный слой.

Ключевые слова: земляное полотно, грунты, покрытия, расчет, усиления.

Strategy of Railway Transport of Ukraine provides for the growth of cargo transportation, construction of new and reconstruction of existing rail lines, the introduction of high-speed and high speed. To achieve these parameters need to develop more sophisticated elements of movement, including the basis for sleepers - roadbed and ballast layer.

The process of strengthening the railway line determined that ensure smooth transportation process on the railways of Ukraine, taking into account the trend of increasing traffic volumes and the introduction of high-speed lines and accelerated passenger traffic requires not simply restoring fixed assets railroad facilities, that is, to bring them to the standard state, and requires fundamental reform and modernization of design elements and technology maintenance and repair of roadbed. It is stated in the "Concept Railways to modernize and develop the railway transport of Ukraine for the next period to 2020."

Keywords: road bed, soil, coating, calculation, amplification.

Вступ. Залізничні мережі багатьох європейських країн, у тому числі України, складаються 3 давно побудованих звичайних ліній, стан і параметри, інфраструктури яких далекі від сучасних вимог. Відсутність належної уваги до колії протягом багатьох років призвело до того, що в цей час ця ситуація потребує вживання радикальних невідкладних заходів. 3 ростом обсягів перевезень та інтенсивності руху поїздів виникла необхідність мати точне уявлення про стан колійної структури i способи оздоровлення земляного полотна за рахунок інноваційних та економічно виправданих технічних рішень.
Основна частина дослідження. У ході дослідження провели масштабні вимірювання, метою яких були оцінка i відстеження найважливіших параметрів, які обумовлюють робочі характеристики ділянки колії. Обрані для вимірювань ділянки мали зони в задовільному і незадовільному стані, а також відзначалися специфічними проблемами.

Застосовані в ході дослідження геофізичні методи, будучи неруйнівними i безпечними, дають змогу визначати різні структури горизонтів грунту, наявність у них води, властивості матеріалів, 3 яких вони складаються, а також можливу наявність тріщин у скельних породах. 
Жорсткість земляного полотна у вертикальному напрямку на всій відстані обстежуваних ділянок вимірювали за допомогою двох розроблених у Швеції та Франції пристроїв.

Для ідентифікації грунтів застосовували геологічні ендоскопи, проникаючі зонди або неруйнівні пробовідбірники. Перевага геологічних ендоскопів перед зондами полягає в збереженні цілісності земляного полотна.

Результати вимірювань жорсткості основи колії можна ефективно використовувати при розробленні технології його поточного утримання, оскільки вони дають змогу виявити першопричини проблем на ділянках 3 незадовільними показниками. Отримані дані можуть бути використані при реконструкції колії з метою підвищення швидкості руху та осьового навантаження, а також при оцінці якості укладання нової колії.

При плануванні реконструкції необхідно розглядати багато аспектів: несучу здатність грунту, опірність земляного полотна впливу різних факторів, майбутню технологію поточного утримання колії. Проте уявлення про стан основи земляного полотна під верхньою будовою колії часто буває неповним через його доступність тільки для візуальних оглядів. У таких випадках вимірювання вертикальної жорсткості дає змогу визначати ділянки, на яких потрібне зміцнення земляного полотна або проведення більш ретельних обстежень.

Земляне полотно експлуатованих ліній має ряд особливостей. У його верхній частині накопичується значний шар баластних $\mathrm{i}$ дренуючих матеріалів, часом товщиною від 1 до 1,5 м і більше. Будівельний майданчик (межа розділу глинистих грунтів і баластних матеріалів) деформується - на ньому утворюються баластні корита i ложа. На значній відстані існує також недостатня ширина земляного полотна зверху і завищена крутість укосів, баластні шлейфи і засмічувачі на укосах насипів. Слід зазначити зсув, як правило, в польову сторону кюветів, нарізаних у дренуючих грунтах, вали забрудненого баласту за кюветами, накопичені при ремонтах колії, місця зі спливів та зсувів укосів насипів, засипані при відновленні дренуючими грунтами.

Особливості стану земляного полотна експлуатованих ліній обумовлені недосконалістю норм проектування, що діяли раніше. Недоліки нормування були усунені 3 введенням в дію будівельно-технічних норм «Залізниці колії 1520 мм», регламентувалося укладання двошарової баластної призми товщиною $55 \mathrm{~cm}$ нижче підошви шпал безпосередньо на глинисті грунти (приблизно $75 \%$ загальної протяжності ліній). Улаштування захисного шару 3 дренуючого грунту під баластною призмою нормами не передбачалося. Через вібродинамічні навантаження від поїздів несуча здатність глинистих грунтів на зазначеній глибині не забезпечувалась, що призвело до пластичних деформацій з утворенням баластних заглиблень на основному майданчику. Через підвищене в 1,2-1,3 рази зволоження глинистих грунтів у місцях 3 такими заглибленнями з'являються осідання колії, спливи і зсуви укосів насипів. У результаті в ряді місць ширина насипів стає недостатньою для розміщення баластної призми. Крім того, в зоні узбіч і укосів насипів грунти перебувають у слабкому стані - пухкий пісок і глинисті грунти пливучопластичні. У результаті руху навантаження від поїзда сприймається призмою з більш міцного грунту 3 крутими стінками безпосередньо під рейкошпальною решіткою. Під навантаженням така призма поступово роздавлюється, і на колії утворюються нерівності (відхилення за рівнем, перекоси, осідання). Тому на нових лініях i додаткових головних коліях, відповідно до норм для запобігання відмічених деформацій $\mathrm{i}$ дефектів у верхній частині земляного полотна передбачене укладання на глинисті грунти захисного шару з дренуючих грунтів товщиною не менше 0,5-1,0 м, у тому числі спільно 3 нетканим матеріалом.

При посиленні підшпальної основи доводиться усувати й запобігати осіданню колії, спливам i зсувам укосів насипів, карстовим провалам, опаданню насипів на болотах і слабких основах. Також необхідно збільшувати ширину земляного полотна зверху i згладжувати круті укоси, ліквідувати деформації у виїмках, розмиви земляного полотна й основ, підмиви укріплень і укосів. Державними та галузевими нормами рекомендується в цих випадках застосування конструкції різного призначення, що розташовуються у земляному полотні на основному майданчику, укосах, у водовідвідних спорудах. У цих конструкціях використовують полістирольні пінопласти, 
гідроізоляційні полівінілхлоридні та поліетиленові плівки, нетканий матеріал голкопробивного виробництва, зварену оцинковану сітку та інші матеріали.

Багаторічні комплексні дослідження дали змогу визначити температурно-деформований стан грунтів земляного полотна 3 теплової та гідравлічної ізоляцією. $\mathrm{Ha}$ основі експериментальних випробувань розроблені нормативні документи щодо стабілізації та посилення земляного полотна.

При розрахунково-теоретичному аналізі використані методи математичного моделювання, гідравлічних аналогій i фізичного моделювання. Було відкрито невідоме раніше термоелектрокінетичне явище в капілярних анізотермічних системах, яке обумовлює перенесення вологи в цих системах. Отримані патенти на розробки.

Розглянемо рекомендовані способи підсилення земляного полотна. За результатами проходів колієвимірювальних вагонів i навантажувальних пристроїв уточнюють місце розташування ділянок 3 деформаціями. Потім на цих ділянках проводиться інженерногеологічне обстеження 3 використанням геофізичних методів (георадіолокація, електроконтактні динамічні зондування та ін.). Додатково проводяться і геологічні роботи 3 улаштуванням виробок - свердловин, шурфів. Склад, властивості і стан грунтів визначають безпосередньо за місцем їх залягання. За характером проходження та відображення електромагнітних імпульсів установлюють місця 3 деформаціями. Міцність грунту при зондуванні визначають за умовним динамічним опором, фіксують слабкі грунти в місцях деформацій.

Для ліквідації осідань колії в складних інженерно-геологічних умовах (близьке, до 1 м, залягання грунтових вод, видавлювання глинистого грунту), а також для усунення інтенсивних розладів рейкової колії за рівнем і в поздовжньому профілі застосовують багатошарове покриття 3 георешітки (зварної сітки) і нетканого матеріалу (рисунок).

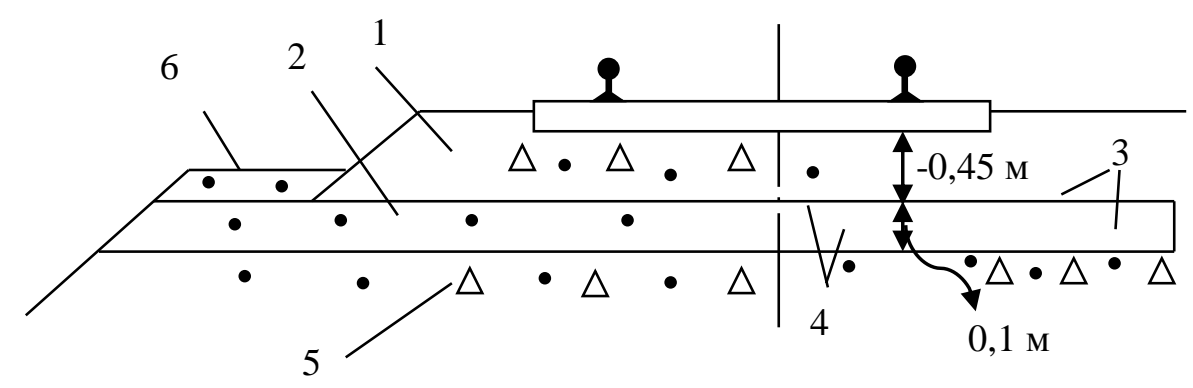

Рис. Багатошарове покриття в поперечному розрізі:

1 - щебінь в баластному шарі; 2 - щебінь між шарами георешітки і нетканого матеріалу;

3 - георешітка; 4 - нетканий матеріал; 5 - забруднений баласт; 6 - шар щебеню на узбіччі

У покритті використовують зварену оцинковану сітку (діаметр дроту 2,5 мм, кроком $50 \times 50$ мм, міцність на розрив не менше $1200 \mathrm{MПа)} \mathrm{і} \mathrm{нетканий} \mathrm{матеріал} \mathrm{голкопробив-}$ ного виробництва (маса $1 \mathrm{M}^{2}-500 \pm 50$ г; розривне навантаження в поздовжньому напрямку - 100 кгс/5 см, у поперечному напрямку - 80 кгс $/ 5 \mathrm{~cm}$, подовження при розриві - від 80 до $110 \%$, коефіцієнт фільтрації не менше 10 м/доб).

Покриття розташовується під баластним шаром і сприймає горизонтальні сили. Це запобігає поперечним горизонтальним переміщенням баласту, так як відбувається армування щебеню між шарами георешітки i нетканого матеріалу. Таке багатошарове покриття в цілому працює як плита. Два шари нетканого матеріалу захищають шар щебеню, що міститься між ними, від засмічення як зверху, так і знизу з основного майданчика. У результаті шар щебеню зберігається в чистому стані та інфільтровані опади відводяться від підшпальної основи убік.

Багатошарове покриття укладають при подвійному очищенні щебеню в ході реконструкції (модернізації) залізничної колії. До влаштування покриття необхідно провести зрізання накопичених баластних матеріалів у 
зоні узбіч 3 використанням машини до проектного рівня підошви баластної призми, а також реконструкцію (ремонт) водовідводів. Зрізання виконують у ході підготовчих робіт.

Висновок 3 дослідження і перспективи, подальший розвиток у даному напрямку. Розрахунком напружено-деформованого стану залізничної колії і його елементів визначено, що конструкція багатошарового покриття зменшує інтенсивність напружень на нижні шари приблизно на $20 \%$. У результаті багаторічних (10 років) експериментальних випробувань встановлено, що на ділянках 3 багатошаровим покриттям осідання колії та інтенсивні розлади рейкової колії за рівнем і в поздовжньому профілі припиняються і земляне полотно стабілізується. Осідання колії і інтенсивність накопичення залишкових деформацій знижуються в кілька разів.

Конструкцію багатошарового покриття проектують відповідно до вимог нормативних документів.

\section{Список використаних джерел}

1. Дыдышко, П.И. Усиление железнодорожного пути в современных условиях [Текст] / П.И. Дыдышко, А.Ю. Абдурашитов // Железные дороги мира. - М., 2012. - № 7. - С. 48-55.

2. Наумов, В.В. Земляное полотно при воздействии повывшенных осевих загрузок. Укрепление основания пути [Текст] / В.В. Наумов, В.В. Виноградов // Путь и путевое хозяйство. M., 2011. - № 5. - C. 22-31.

3. Смоляницкий, Л.А. Влияние капиллярных процессов в земляном полотне на развитие эффектов [Текст] / Л.А. Смоляницкий, А.В. Сычева //Путь и путевое хозяйство. - М., 2012. - № 4. C. 20-21.

4. Смоляницкий, Л.А. Необходимое условие - стабильный путь [Текст] / Л.А. Смоляницкий // Путь и путевое хозяйство. - М., 2012. - № 5. - С. 30-31.

5. Укрепление основания пути [Текст] //Железные дороги мира. - М., 2011. - № 5. - С. 68-70.

Рецензент д-р техн. наук, професор О.М. Даренський

Прокопенко Олексій Іванович, викладач Одеського коледжу транспортних технологій, магістр ІППК Української державної академії залізничного транспорту, 65028, Одеса, пл. Олексіївська 17, к. 210, т. 048-72760-32, 067-559-19-30, Email: oleksiyprokopenko@gmail.com.

Мануйленко Володимир Григорович, канд. техн. наук, доцент секції кафедри колії та колійного господарства Української державної академії залізничного транспорту. Тел. 057-730-10-62.

Prokopenko Alexei Ivanovich, Odessa College Lecturer transport technologies, student - Master of IPPK Ukrainian State Academy of Railway Transport, 65028, Odessa, pl. Alekseevskaya 17 k.210, Vol.048-727-60-32, 067-559-19-30, Email: oleksiyprokopenko@gmail.com.

Manuylenko Vladimir G., cand. of techn. sciences, Assistant Professor Section of the Department: "Track and track sector" Ukrainian State Academy of Railway Transport, 61050, Kharkiv, pl. Feyerbaha, 7, Faculty of Engineering, Vol. 057-730-10-62. 